\title{
Respon Pertumbuhan Ikan Nila (Oreochromis niloticus) yang diberi Pakan Supplementasi Bawang Putih (Allium sativum) pada Sistem Bioflok
}

\author{
Growth Response of Tilapia (Oreochromis niloticus) fed Garlic (Allium \\ sativum) Supplementation Feed in Biofloc System
}

\author{
Muhammad Azharul Rijal ${ }^{*}$, Cahyono Purbomartono², Izanatu Fahthulil \\ Jannah $^{3}$ \\ 1,2 Jurusan Akuakultur, Universitas Muhammadiyah Purwokerto \\ ${ }^{3}$ Pendidikan Biologi, Universitas Muhammadiyah Purwokerto \\ *corr-author: azharul.rijal@gmail.com
}

\begin{abstract}
ABSTRAK
Ikan nila (Oreochromis niloticus) merupakan salah satu komoditas unggulan perikanan yang seiring dengan meningkatnya permintaan di pasaran, ssehingga produktivitasnya harus dipacu terus menerus dengan berbagai teknolgi akuakultur sistem intensif. Penelitian ini bertujuan untuk mengetahui pengaruh pemberian ekstrak bawang putih melalui pakan dalam meningkatkan pertumbuhan ikan nila yang dipelihara dalam sistem bioflok. Penelitian dilaksanakan pada bulan Maret sampai bulan Juni 2021 di Laboratorium Basah Kolam Bioflok. Penelitian menggunakan metode eksperimen berupa Rancangan Acak Lengkap dengan 3 perlakuan 1 kontrol serta 3 kali ulangan. Parameter yang diamati berupa parameter pertumbuhan meliputi pertambahan berat dan panjang, laju pertumbuhan spesifik (spesific growth rate/SGR), konversi pakan (food convertion ratio/FCR), dan efisiensi pakan serta jumlah flok yang terbentuk dalam ember kultur. Parameter pendukung berupa kualitas air yang meliputi suhu dan $\mathrm{pH}$. Data dianalisis menggunakan ANOVA (Analysis of Variance) pada taraf kepercayaan 95\%, dilanjutkn dengan uji DMRT (Duncan Multiple Range Test). Data kualitas air dianalisis secara deskriptif. Penambahan serbuk bawang putih (Allium sativum) dalam pakan untuk meningkatkan pertumbuhan ikan nila (O. niloticus) hanya berpengaruh nyata pada pertambahan panjang dan SGR, sedangakan pertambahan berat dan FCR serta efisiensi pakan tidak berbeda nyata. Dosis optimum yang mampu meningkatkan pertumbuhan ikan nila yaitu pada P3 22,5 g/kg pakan. Berdasarkan penelitian ini, pemberian serbuk bawang putih melalui pakan berpotensi meningkatkanpertumbuhan ikan nila yang dipelihara dalam sistem bioflok.
\end{abstract}

Kata-kata kunci: Ikan nila (Oreochromis niloticus), bawang putih (Allium sativum), pertumbuhan, bioflok

\begin{abstract}
Tilapia (Oreochromis niloticus) is one of the leading fishery commodities which is increasing market demand, so that its productivity must be continuously boosted by various aquaculture intensive system technologies. The research aim is to know growth response in tilapia has supplementation with garlic powder and to know the best dosage to improve growth response. The research was carried out from March to June 2021 at the Biofloc Pond Wet Laboratory. The study implemented an experimental method of a completely
\end{abstract}


randomized design with 3 treatments, 1 control and 3 replications. Parameters observed were growth parameters including weight and length gain, spesific growth rate (SGR), feed conversion (FCR), and feed efficiency as well as the number of flocs formed in culture buckets. The supporting parameters were water quality which includes temperature and pH. Data were analyzed using Analysis of Variance (ANOVA) at the 95\% confidence level, followed by the Duncan Multiple Range Test (DMRT). Water quality data were analyzed descriptively. The addition of garlic powder (Allium sativum) in feed to increase the growth of tilapia (O. niloticus) only had a significant effect on length and SGR, while weight gain and FCR and feed efficiency were not significantly different The optimum dose that could increase tilapia growth was at P3 $22.5 \mathrm{~g} / \mathrm{kg}$ feed. Based on this research, the application of garlic powder through feed has the potential to increase the growth of tilapia reared in a biofloc system

\section{Keywords: Tilapia (Oreochromis niloticus), garlic (Allium sativum), growth, biofloc}

\section{PENDAHULUAN}

Industri akuakultur adalah salah satu industry dengan pertumbuhan yang sangat pesat secara global. Akuakultur menyumbang $47 \%$ dari produksi ikan secara global. (Valenzuela-Gutiérrez \& Lago-Lestón, 2021). Salah satu komoditi unggulan dari perikanan adalah ikan Nila. Ikan nila adalah ikan asli dari benua Afrika yang masuk ke Indonesia dan secara massal berkembang. Tingkat penggunaan ikan nila sebagai komoditas budidaya sengat luas hingga menjadikan ikan ini menjadi komiditas yang sangat penting di budidaya ikan secara global (Jegede, 2012). Jumlah produksi ikan nila ini secara global mampu menembus angka 1.49 metrik ton per tahun. Namun ada beberapa kendala yang sering menjadi masalah pada produksi ikan nila ini. Masalah pada budidaya ikan nila yang sering terjadi adalah : serangan penyakit yang disebabkan bakteri atau virus, lembat nya pertumbuhan dan kurang efektif nya pertumbuhan pada ikan Nila (Ndong \& Fall, 2011). Pemberian pakan dengan ekstrak bawang putih merupakan salah satu solusi yang bisa dipakai untuk mengatasi permasalahan pada proses produksi di budidaya ikan Nila ini.

Bawang putih (Allium sativum) yang termasuk dalam genus Allium telah digunakan sejak lama sebagai bahan perasa dan obat tradisional untuk meningkatkan kesehatan (Lee, Ra, Song, Sung, \& Kim, 2012). Penggunaan bawang putih sebagai bahan tambahan pangan dapat meningkatkan imunitas. Senyawa aktif yang terkandung pada bawang putih seperti alisin, scordinin, ajoene dan flavonoid dipercaya dapat meningkatkan kesehatan dan kondisi fisiologis manusia dan hewan vertebrata (Lukistyowati \& Kurniasih, 2011). Pemberian ekstrak dari bawang putih ini dapat mempengaruhi pertumbuhan dan meningkatkan resistensi terhadap penyakit pada ikan. (Kustiana \& Suseno, Potensi Campuran Bubuk Meniran (Phyllanthus niuri) dan Bawang Putih (Allium sativum) Terhadap Pertumbuhan Ikan Lele Dumbo (Clarias gariepinus), 2021). Suplementasi bawang putih pada pakan dapat meningkatkan performa pertumbuhan pada ikan lele. Bawang putih memiliki kempauan untuk meningkatkan aktivitas katalis pada serum dan menurunkan level plasma glukosa pada ikan (Nwabueze, 2012).

Tujuan peneltian ini adalah untuk mengetahui respon pertumbuhan ikan yang diberikan pada supplementasi bawang putih pada system bioflok dan untuk mengetahui dosis yang terbaik untuk meningkatkan respon pertumbuhan pada ikan tersebut pada system bioflok. 


\section{METODE PENELITIAN}

\section{Alat dan Bahan}

Bahan yang digunakan adalah ekstrak bawang putih probiotik dan prebiotic. Sedangkan bahan yang digunakan adalah benih ikan Nila

\section{Pembuatan Ekstrak Bawang Putih}

Pembuatan ekstrak bawang putih dilakukan metode ekstrak kering. Bawang putih di kupas dan dipotong kecil kemudian di jemur. Bawang putih yang telah kering kemudian di blender dan disimpan pada wadah yang kering.

\section{Persiapan Pakan}

Serbuk ekstrak bawang putih dilarutkan pada akuades sesuai dosis yaitu $0 \mathrm{~g} / \mathrm{Kg}(\mathrm{P} 0)$ 7,5g/Kg (P1), 15g/Kg (P2), 22,5g/Kg (P3) pakan komersial. Semprotkan hasil pencampuran tersebut pada pakan, kemudian jemur dan keringkan. Simpan pada wadah yang tertutup dan kering.

\section{Pembuatan Media}

Media pemeliharaan dilakukan pada ember dengan volume $56 \mathrm{~L}$. sebanyak 21 gram garam dilarutkan pada media. Kemudian dimaskukkan 4ml EM4 dan 16ml Molase. Tunggu sekitar 2 minggu hingga media siap.

\section{Pertumbuhan Mutlak}

Pertumbuhan mutlak ikan dihitung dengan membandingkan berat dan panjang awal ikan sebelum dan sesudah penelitian berlangsung. Pertumbuhan mutlak panjang dan berat dapat dihitung dengan persamaan (1) dan (2).

W : pertumbuhan berat mutlak

$$
\begin{aligned}
\mathrm{W} & =\mathrm{Wt}-\mathrm{Wo} \\
\mathrm{L} & =\mathrm{Lt}-\mathrm{Lo}
\end{aligned}
$$

Wt : bobot ikan pada akhir perlakuan (gram)

Wo : bobot ikan pada awal perlakuan (gram)

L : pertumbuhan mutlak panjang

Lt : penjang ikan pada akhir perlakuan $(\mathrm{cm})$

Lo : panjang ikan pada awal perlakuan $(\mathrm{cm})$

\section{Efisiensi Pakan}

Efisiensi pakan dilakukan untuk melihat serapa efektif pakan ekstrak bawang ini dikonsumsi oleh ikan uji. Efisiensi pada di hitung dengan persamaan (3).

$$
\mathrm{EP}=\frac{W t-W o}{F} \times 100 \%
$$

EP : Efisiensi pakan

$\mathrm{F}:$ Jumlah pakan yang diberikan (gram)

Wt : Bobot ikan pada saat akhir perlakuan (gram)

Wo : bobot ikan saat awal perlakuan (gram)

\section{Konvesi Pakan FCR}


Konversi pakan adalah indikator dari kenaikan biomassa ikan pemeliharan. Rasio konversi pakan dapat dihitung dengan persamaan (4).

$$
\mathrm{FCR}=\frac{W t-W o}{F}
$$

FCR : Rasio Konversi pakan

F : Jumlah pakan yang diberikan (gram)

Wt : Bobot ikan pada saat akhir perlakuan (gram)

Wo : bobot ikan saat awal perlakuan (gram)

\section{Kualitas Air}

Parameter kualitas menjadi parameter pendukung yang mengindikasikan media pemeliharaan dapat kondisi maksimal. Parameter tersebut adalah : temperature dan derajat keasaman.

\section{Analisis Data}

Analisis data dalam penelitian menggunakan perhitungan program SPSS Analysis of Variance (ANOVA) satu jalur pada taraf kepercayaan 95\% $(\alpha=0,05)$. Jika uji $\mathrm{F}$ menunjukkan perbedaan yang nyata, maka dilanjutkan dengan uji Duncan Multiple Range Test (DMRT) pada taraf kepercayaan 95\% untuk mengetahui signifikansi antar perlakuan. Data kualitas air yang melipti suhu dan $\mathrm{pH}$ air dianalisis secara deskriptif kualitatif.

\section{HASIL DAN PEMBAHASAN}

Tabel 1 menunjukkan hasil dari uji statistic ragam dengan taraf kepercayaan 95\% menunjukkan pemberian pakan ikan dengan level suplemetasi bawang putih yang berbeda dosis memberikan perbedaan yang nyata antar perlakuan. Hasil analisis pertambahan berat, panjang dan SGR menunjukkan perlakuan P3 (dengan suplementasi 22,5g/Kg) memiliki perbedaan yang nyata jika dibandingkan dengan perlakuan lainnya.

Tabel 1. Pertambahan berat dan panjang, laju pertumbuhan harian (SGR), konversi pakan, dan efisiensi pakan

\begin{tabular}{ccccc}
\hline & P0 & P1 & P2 & P3 \\
\hline Wt & $9.57 \pm 0,32^{\mathrm{b}}$ & $9,13 \pm 0,09^{\mathrm{a}}$ & $9,14 \pm 0,16^{\mathrm{a}}$ & $9,66 \pm 0,21^{\mathrm{b}}$ \\
Lt & $5,90 \pm 0,21^{\mathrm{a}}$ & $6,19 \pm 0,03^{\mathrm{b}}$ & $5,71 \pm 0,19^{\mathrm{a}}$ & $6,36 \pm 0,10^{\mathrm{b}}$ \\
SGR & $2,29 \pm 0,02^{\mathrm{a}}$ & $2,27 \pm 0,02^{\mathrm{a}}$ & $2,28 \pm 0,02^{\mathrm{a}}$ & $2,35 \pm 0,02^{\mathrm{b}}$ \\
FCR & $1,66^{\mathrm{a}}$ & $1,66^{\mathrm{a}}$ & $1,67^{\mathrm{a}}$ & $1,62^{\mathrm{ab}}$ \\
FE & $1,37^{\mathrm{ab}}$ & $1,33^{\mathrm{a}}$ & $1,32^{\mathrm{a}}$ & $1,40^{\mathrm{a}}$ \\
\hline
\end{tabular}

Keterangan: Nilai dengan superscript yang sama pada tabel menunjukkan tidak ada perbedaan yang nyata (rata-rata $\pm \mathrm{SD}, \mathrm{n}=5>0,05$ ), sedangkan nilai dengan superscript yang berbeda pada tabel menunjukkan perbedaan yang nyata antar perlakuan (rata-rata \pm $\mathrm{SD}, \mathrm{n}=5>0,05)$. Wt:weight total, Lt:length total, SGR:Specific Growth Rate, FCR:Food Convertion Ratio, FE:Food Efficiency

Pemberian suplementasi 22,5g/Kg mampu meningkatkan pertumbuhan berat ikan Nila sebanyak 9,66 gram, pertambahan panjang ikan sebesar 6,36 cm dan tingkat SGR mencapai 2,35. Sedangkan untuk nilai FCR dan FE tidak ada berbedaan nyata antar pelakuan. Nilai FCR terbaik ada pada P3 yang menunjukkan nilai 1,62. FCR atau Food Convertion Ratio adalah suatu ukuran yang menyatakan rasio jumlah pakan yang dibutuhkan untuk menghasilkan berat $1 \mathrm{~kg}$ bobot ikan (Effendie, 2002). Nilai FCR pada penelitian ini yang terbaik adalah 1,62 dengan pengertian ikan dapat meningkatkan bobot biomass $1 \mathrm{~kg}$ jika 
diberikan pakan $1,62 \mathrm{~kg}$. Efisiensi pakan merupakan perbandingan antara jumlah pakan yang diberikan dengan pertambahan bobot biomassa ikan diakhir penelitian. Nilai efisiensi pakan pada penelitian ini memiliki nilai terbaik 1,40.

Hal ini menunjukkan ada respon positif antara suplementasi tepung bawang putih dengan pertumbuhan ikan. Bawang putih diketahui sebagai bahan pangan pertama yang dapat meningkatkan pertumbuhan dan pencegahan terhadap serangan penyakit. Kandungan dari bawang putih seperti allicin dilaporkan dapat meningkatkan performa pencenaan ikan Nila. Kandungan ini pula yang dapat meningkatkan aktivias enzim pencernaan dan menstimulasi kinerja dari pencernaan (Maniat, Negar, \& Ghatrami, 2014). Hasil penelitian ini sesuai dengan penelitian yang dilakukan oleh (Agbebi, Ogunuyiwa, \& Herbert, 2013) yang menyatakan bahwa penambahan ekstrak bawang putih sebanyak 30\% dalam pakan dapat meningkatkan performa pertumbuhan dan tingkat kelangungan hidup ikan Lele. Penelitian pun menjelaskan bahwa tidak ada pengaruh negative dari pemberikan ekstrka bawang putih dalam pakan untuk ikan. Hal ini sesuai dengan penelitian yang dilakukan oleh (Kustiana \& Suseno, 2021) yang menyatakan bahwa penembahan pakan dengan simplisia dan ekstrak bawang putih sebanyak $29 \mathrm{~g} / \mathrm{kg}$ pakan ikan dapat meningkatkan bobot ikan hingga 87gram. Hasil penelitian menunjukkan nilai SGR tertinggi ada pada P3 dengan dosis suplementasi $22,5 \mathrm{~g} / \mathrm{Kg}$. Nilai SGR yang berbeda nyata pada P3 membuktikan bahwa kandungan alisin yang berfungsi sebagai zat yang dapat memacu gerakan sistem pencernaan pada ikan Nila (Marentek, H, \& SNJ, 2013).

Nilai FCR dan FE merupakan indikator dari pertumbuhan dan tingkat konsumsi ikan dengan pellet ikan. Penelitian yang dilakukan oleh (Lee, Ra, Song, Sung, \& Kim, 2012) menunjukkan bahwa pakan yang dikonsumsi oleh ikan lebih efisien untuk pertumbuhan. Dari penelitian ini sebanyak satu kilogram bobot biomassa ikan dapat meningkat pada pemberian pakan $1,62 \mathrm{~kg}$.

Pada penelitian yang lain pemberian dosis suplementasi tepung bawang putih yang terlalu tinggi dapat mengurangi nafsu makan ikan dan efisiensi pakan ikan. Hal ini dikarenakan aroma dari bawang putih yang kurang disukai oleh ikan jika pada dosis tinggi suplementasi bawang putih. (Maniat, Negar, \& Ghatrami, 2014).

Sistem bioflok merupakan tekonologi dalam budaidaya perikanan yang dapat meningkatkan kualitas perairan dengan memperhatikan kompisisi carbon dan nitrogen. Karbon yang ditambahkan pada kolam bioflok dapat meningkatkan terbentuknya pakan alami yang terbentuk (Crab, Defoirdt, Bossier, \& W, 2012). Suspensi dari flok yang terbentuk pada bioflok dapat bersisi pakan alami yaitu phytoplankton, zooplankton, bakteri dan bahan organic lain. Kandungan dari pakan alami ini lah yang dapat menjadi alternatif dan sumber pakan alami bagi ikan pada sistem bioflok (Long, Yang, Yuan, Chongwu, \& Fan, 2015).

Selama penelitian menunjukkan bahwa data atau nilai kualitas air dalam rentang yang baik dan dapat menunjang kehidupan ikan. Kisaran temperature air selama penelitian adalah $26-27^{\circ} \mathrm{C}$. Nilai pH selama penelitian memiliki kisaran $6-7,5$. Kualitas air selama penelitian merupakan range yang baik dan dapat menopang pertumbuhan ikan secara maksimal.

\section{KESIMPULAN}

Penambahan serbuk bawang putih (Allium sativum) dalam pakan dapat meningkatkan performa dan respon pertumbuhan ikan nila (Oreochromis niloticus) pada dosis suplementasi P3 22,5g/Kg pakan ikan. Dosis terbaik pada penelitian ini adalah $22,5 \mathrm{~g} / \mathrm{Kg}$ pakan ikan. Dosis tersebut yang dapat meningkatkan respon pertumbuhan ikan nila dilihat dari pertambahan berat, pertembahan panjang, laju pertumbuhan harian, koversi pakan, dan efisiensi pakan. 


\section{DAFTAR PUSTAKA}

Agbebi, O. T., Ogunuyiwa, T. G., \& Herbert, S. M. (2013). Effect of Dietary Garlic Source oh Feed Utilization, Growth and Histopathology of the African catfish (Clarias gariepinus). Journal of Agricultural Science, 26-34.

Andriani, C., Hastuti, S., \& Sarjito. (2017). Peran bawang Putih dalam Pakan Sebagai Immunostimulan Terhadap Kondisi Kesehatan, Kelulushidupan, dan Pertumbuhan Ikan Tawes (Puntius javanicus). Journal of Aquaculture Management and Technology, 59-67.

Crab, R., Defoirdt, T., Bossier, P., \& W, V. (2012). Biofloc technology in Aquaculture: Beneficial effect and Future Challenges. Aquaculture, 351-356.

Effendie, H. (2002). Biologi Perikanan . Yayasan Pustaka Nusantara, 50-62.

Jegede, T. (2012). Effect of Garlic (Allium sativum) on Growth, Nutrient Utilization, Resistance and Survival of Tilapia zillii (Gervais 1852) Fingerlings. Journal of Agricultural Science, 269-274.

Kustiana, M., \& Siseno, D. N. (2021). Potensi Campuran Bubuk Meniran (Phyllanths niruri) dan Bawang Putih (Allium sativum) Terhadap Pertumbuhan Ikan Lele Dumbo (Clarias gariepenus). Jurnal Grouper, 33-37.

Kustiana, M., \& Suseno, D. N. (2021). Potensi Campuran Bubuk Meniran (Phyllanthus niuri) dan Bawang Putih (Allium sativum) Terhadap Pertumbuhan Ikan Lele Dumbo (Clarias gariepinus). Jurnal Grouper, 33-37.

Lee, D.-H., Ra, C.-S., Song, Y.-H., Sung, K.-I., \& Kim, J.-D. (2012). Effect of Dietary Garlic Extract on Growth, Feed Utilization and Whole Body Composition of Juvenile Sterlet Sturgeon (Acipenser ruthenus). Asian-Aust. Journal Aminal Science, 577-583.

Long, L., Yang, J. L., Yuan, G., Chongwu, W., \& Fan. (2015). Effect of Biofloc tecnology on Growth, digestive enzyme activity, hematology and immune respone of genetically improved farmed tilapia (Orechromis niloticus). Aquaculture, 12-18.

Lukistyowati, I., \& Kurniasih. (2011). Kelangsungan Hidup Ikan Mas (Cyprinus carpio L) yang Diberi Pakan Ekstrak Bawang Putih (Allium sativum) dan di Infeksi Aeomonas Hydrophila. Jurnal Perikanan dan Keluatan , 144-160.

Maniat, M., Negar, G., \& Ghatrami, E. R. (2014). Effect of garlic on growth performance and body composition of Benni Fish (Mesopotamichtys sharpeyi). International Journal of Biosciences, 269-277.

Marentek, G., H, M., \& SNJ, L. (2013). Evaluation of The Usof Garlic (Allium sativum) in Enhancing Nonspecific Immune Respone and Growth of Nile Tilapia (Oreochromis niloticus). EJournal Budidaya Perairan, 1-7.

Ndong, D., \& Fall, J. (2011). The effect of garlic (Allium sativum) on growth and immune responses of hybrid tilapia (Oreochromis niloticus x Oreochromis aureus). Journal of Clinical Immnunology and Immunopathology Research, 1-9.

Nwabueze, A. A. (2012). The Effect of Garlic (Allium sativum) on Growth and Haematological Parameters of Clarias gariepinus (Burchell, 1822). Sustainable Agriculture Research, 222-228.

Valenzuela-Gutiérrez, R., \& Lago-Lestón, A. (2021). Exploring the garlic (Allium sativum) properties for fish aquaculture. Fish Physiol Biochem, 1179-1198. 